\title{
“ 'SCHWEDIS' HE CAN'T EVEN SAY SWEDISH” - SUBVERTING AND REPRODUCING INSTITUTIONALIZED NORMS FOR LANGUAGE USE IN MULTILINGUAL PEER GROUPS
}

\author{
Ann-Carita Evaldsson and Asta Cekaite
}

\begin{abstract}
The present study explores how minority schoolchildren in multilingual peer group interactions act upon dominant educational and linguistic ideologies as they organize their everyday emerging peer culture. The data draw from ethnographies combined with detailed analysis (CA) of video recordings in two primary monolingual school settings in Sweden. Bakhtin's processual view of how linguistic norms are used for overcoming the heteroglossia of language is used as a framework for understanding how monolingualism is talked-into-being in multilingual peer groups. As will be demonstrated, the children recurrently participate in corrective practices in which they playfully exploit multiple linguistic resources (syntactic, lexical and phonetic features) and the turn structure of varied activities (conflicts, accusations, insults, classroom discourse) to play with and consolidate a collective critical view of not-knowing correct Swedish. Moreover, they transform faulty talk (repeating structural elements, recycling arguments, using parodic imitations, joint laughter, code-switching) to display their language competence, assert powerful positions and strengthen alliances in the peer group. It is argued that such forms of playful heteroglossic peer group practices are highly ambiguous and paradoxically tend to enforce power hierarchies and values associated with different social languages and codes, thus co-constructing the monolingual ideology.
\end{abstract}

Keywords: Multilingual peer group interaction; Corrective practices; Linguistic ideologies; Monolingual norms; Educational settings; Heteroglossia in practice.

\section{Introduction}

A growing number of studies have demonstrated that adolescents in multilingual peer groups creatively explore, contest and resist the monolingual ideology they experience in their everyday school lives (Jørgensen 2005; Rampton 1995, 2006). Particularly Rampton (1995: 280) demonstrates how a group of adolescents in London use crossing and switches into languages (i.e., Caribbean Creole English, Punjabi and other varieties) "not generally thought to belong to" them. It is argued that adolescents, through their participation in such forms of language experimentation that move across social and linguistic boundaries, create hybrid forms of language that (indirectly) challenge a monolingual unitary code. Other studies show how Turkish adolescent boys' and girls' switches between multiple languages provide a resource for power wielding that is also used as a means for resisting a monolingual ideology and adult-based norms for language use (see Jørgensen 2005). This line of research provides an understanding of 
how adolescents, in their interactions, develop multilingual practices with peers by exploiting existing societal power structures (see also Madsen 2008). However, thus far, few studies have explored communicative practices among minority schoolchildren in multilingual peer groups as they act upon institutionalized norms for language use in monolingual educational settings.

In the present study, data are drawn from ethnographic research combined with video recordings of minority schoolchildren's everyday interactions in two primary monolingual educational school settings in Sweden, where the official language is Swedish. Of interest is how the children, when participating in corrective routines, appropriate and even subvert dominant language ideologies based on notions of correct and appropriate forms of Swedish. Monolingual educational settings represent a complex array of institutionalized practices in which adults/teachers regulate language use, including students' language choice, good or bad and right or wrong language (Cekaite \& Evaldsson 2008). In what follows we will show how Bakhtin's concept of heteroglossia provides ways for understanding the social processes that guide how norms for language use are talked-into-being and appropriated in multiethnic educational settings where a monolingual ideology is the norm and children's social languages differ substantially from the institutional expectations for appropriate language use. As Bakhtin notes (1986: 270)

"A unitary language is not something given [dan] but is always an essence posited [zadan] - and at every moment of its linguistic life it is opposed to the realities of heteroglossia. But at the same time it makes its real presence felt as a force for overcoming this heteroglossia, imposing specific limits to it, guaranteeing a certain maximum of mutual understanding and crystallizing into a real, although still relative, unity - the unity of the reigning conversational (everyday) and literary language, "correct language".

Bakhtin's processual view of a unitary language underscores the creative and restraining forces of linguistic norms as they struggle to overcome the heteroglossia of language. What we have here is not only languages in a strict sense but also - and for Bakhtin this is the essential point - "languages that are socioideological: Languages of social groups", "professional" languages, languages of generations and so forth." (ibid.: 270). The fact that the concept of heteroglossia covers socially stratified language varieties allows us to achieve a nuanced understanding of how and where a unitary language 'comes from'. Unitary language as practiced in a monolingual educational setting thus concerns not only the use of different codes, but also 'correct' language and the use of bad language more generally.

Practices that impose unitary language exemplify the phenomenon that Cameron calls verbal hygiene (1995: 1), which comes into being when someone enforces particular language norms and notions about how language ought to work. In addition to institutional, educational agendas for the use of correct and proper Swedish, such practices comprise non-institutional peer group interactions such as minority schoolchildren playfully commenting on and criticizing one another's Swedish or bad language(s) more generally. By exploring these corrective routines, we will demonstrate some of the ways in which norms for majority language use are talked-into-being, appropriated and even resisted by minority children. Within such an understanding of language use as a socio-ideologically situated process, we argue, one can contribute to a 
more comprehensive view of the linguistic and cultural competencies minority children display in educational settings with a monolingual ideology.

\section{Children's peer group interactions as a language socialization context}

A commonly held belief is that children become sensitive to prestige norms of language use through the interventions of their parents and, more decisively, their teachers (see Cameron 1995). However, as has been demonstrated in studies of children's peer language practices, children do not simply passively reproduce adult linguistic ideologies, but creatively appropriate linguistic ideologies and institutionalized norms for language use, contributing to the creation, recreation and maintenance of these ideologies (see other contributions in this volume). In their peer interactions, children have been observed to use an array of linguistic practices to mock, comment on and resist adult-based rules and dominant institutional ideologies, including language, age, gender and ethnicity (see Goodwin \& Kyratzis, in press, for an overview).

Particularly language socialization studies on children's peer interactions in noninstitutional bilingual settings (i.e., at home and in the neighbourhood) have shown that children's peer interactions provide an important context for linguistic and cultural socialization (Paugh 2005; see also Garrett 2000; Kulick 1992; Rindstedt \& Aronsson 2002). For example, Rindstedt and Aronsson (2002) have shown that despite adults' efforts to instill children's learning and use of Quichua, sibling interactions in Spanish provided a powerful factor that contributed to the children's monolingualism. Garrett (2000, 2007), on the other hand, demonstrates how children in Morne-Carré transform and resist adults' efforts to socialize younger children to use English. Despite the agebased restrictions on the use of Kwéyòl, the children, particularly as they grow older, draw on both English and Kwéyòl to (re)position themselves in relation to other children. Moreover, Paugh (2005: 80) demonstrates how children, in their codeswitching practices in peer-kin groups in Dominica, "transform the associations with the languages through using them in their play". Although they were forbidden to speak Patwa (a French-lexicon creole), they used it in their role-play to enact adult roles and create imaginary play spaces, possibly supporting the maintenance of indigenous languages in the region. In addition, in her ethnographic work among Miskitu children on Corn Island, Minks (see this volume) shows how the children, in their peer group interactions, "displayed an ideology of language mixing that reflects their ambiguous positioning in a multilingual community". Thus, peer language socialization studies have generally shown how children in non-institutional settings have a critical role in the exploration and future development of local ideologies of language, and the differential use and values associated with two or more normatively defined codes.

In the present study, we apply the language socialization approach to explore how children in an institutional school setting act upon and exploit institutionalized language norms as available cultural resources for constructing and reshaping the social organization of their multicultural peer group (see also Kyratzis, this volume). Of particular interest are the communicative competencies minority schoolchildren with diverse ethnic and linguistic backgrounds display in corrective routines, such as when they playfully comment on, mimic and criticize one another's Swedish or bad language(s) more generally. In addition to children's immediate interactional concerns, 
we are interested in how wider societal and educational frameworks of linguistic stratifications are located and mobilized within children's peer group practices.

\section{Monolingual educational ideologies in European and Swedish context}

In Sweden, where the present study was conducted, educational policy (cs. the Swedish national curriculum, CCSS, 1994) promotes immigrant children's mastery of the official language of the nation, government, administration and school - that is Swedish. Several European countries such as Denmark (Jørgensen 1998) Spain (Woolard 1997), Germany (Hinnenkamp 2003), Greece (Lytra 2007), and England (Rampton 1995) share a similar history of linguistic unification and centralization in both society at large and in the educational system. Sweden, despite rather extensive immigration during the past 50 years, can be seen as a monolingual country, striving for homogeneity, rather than heterogeneity. The great emphasis on Swedish constitutes part and parcel of wider societal and political processes that formulate integration as an issue of language, i.e., 'proper' mastery of the majority language. During recent decades, the call for language competencies in the official language have become an even more urgent part of new immigration policies.

In Sweden, two forms of educational programmes have been developed to provide such language competencies for children with minority backgrounds, these are the socalled "reception" classes and regular school classes. Reception classes are a specialized and separate form of education, aimed at introducing recently arrived immigrant children to the Swedish language, and preparing them for transfer to regular classes. The second form of educational programme involves minority children who are integrated into regular classes from the beginning. In both types of classes, independent of children's ethnic and linguistic backgrounds, classroom instructions are exclusively given in the majority language that is Swedish. All students with immigrant backgrounds are entitled to instruction in their mother tongue a couple hours a week, however, the implementation of this educational policy is still problematic.

The present study puts together ethnographic work from the two monolingual educational forms attended by minority children in Sweden (Cekaite 2007; Evaldsson 2004, 2005). The fact that we have collected long-term data from two different educational settings that both orient towards monolingual educational agendas allows us to explore and to paint a broader picture of the societal processes, with a focus on how linguistic ideologies are locally accomplished among minority school children. Taken together, the analysis will provide a deeper understanding of how children, across various educational contexts and in their everyday multilingual peer interactions, appropriate (i.e., subvert or reproduce) dominant normative practices for language use.

\section{Educational settings, children and multilingual peer groups}

The data draw on ethnographies combined with recordings of minority schoolchildren's peer interactions on the playground and in classrooms in the two different educational school settings (i.e., one year at a reception class and one-year at a regular class) in Sweden, where linguistic ideologies concern the use of proper and correct Swedish (as described above). 
Ethnographic work was combined with videorecordings (90 hours) of classroom and playground interactions, documented during one school year in one reception class (for more details, see Cekaite 2007). The reception class was integrated into a regular Swedish primary school in a suburban multiethnic residential area with a high percentage of students with a home language other than Swedish (approximately 70\%, including Arabic, Spanish, Somali, Serbo-Croatian, Kurdish, and other languages). 'Reception' classes constitute a specialized form of education, aimed at introducing children to the Swedish language and at preparing them for transfer to regular classes, that is, introducing them to the Swedish educational system and Swedish school culture. The class was attended by seven beginning learners of Swedish, who had recently arrived to Sweden. The children in focus were 7- to 10-year-olds from Iraq (Fadi, Rana and Layla), Kurdistan in Iraq (Fusi, Hiwa) and in Turkey (Sawan), and from Thailand (Nok). Besides using Swedish in the classroom and on the schoolyard, the children with a Kurdish background used rudimentary features of Arabic that they had learned from their Arabic peers on the playground.

The second ethnography was conducted in two first grade classrooms in a primary school where minority schoolchildren were integrated into Swedish reading classes independent of ethnic and linguistic background (for further details, see Evaldsson 2005). Children's peer group interactions in the classrooms (50 hours) and on the playground (50 hours) were documented over a period of a year. In all, around 200 students from preschool through third grade, 6-10 years of age, attended the school. Most students came from an inner-city multiethnic residential area where, according to Swedish standards, families had socioeconomic problems. The children that are in focus in the selected series of extracts belonged to a loosely coupled multilingual peer group consisting of six children, 4 boys (Elias, Jamie, Mario, Shafi) and 2 girls (Lisa, Tatja), between 7 to 8 years with diverse ethnic backgrounds (mainly Syrian and Romany) and from low-income immigrant families. Two of the children (Elias and Lisa) were Syrian, three of them (Jamie, Tatja and Mario) Romany and one child (Shafi) Somalian. According to teachers, the two boys, Jamie and Elias, lacked competencies in the formal structure (grammar and lexis) of the Swedish language and were in need of special education. On the schoolyard, Elias, Lisa, Mario, Norma and Tatja used Swedish, while Jamie most often used Romany in in-group peer interaction.

In both settings, multilingual peer groups were formed out of preadolescent children with mixed ethnic and linguistic backgrounds. Swedish constituted a kind of lingua franca in multilingual peer groups both on the schoolyard and in classrooms. Minority languages were occasionally used in in-group peer interactions among children with similar ethnic and linguistic backgrounds. In both these settings, teachers were monolingual speakers of Swedish. The use of minority languages was not forbidden, but not encouraged by the teachers (Cekaite \& Evaldsson 2008). Parents were also highly aware of the need to teach children Swedish and concerned that the use of minority languages might hinder children's acquisition of the majority language. Teaching children correct Swedish (phonology, grammar, lexis, pragmatics, literacy skills) was embedded in the curriculum agenda and served as an implicit norm that was seldom explicitly articulated by the teachers in everyday classroom practice. In addition, teachers produced clear guidelines on and organized teaching about non-sexist language and bad language more generally, such as swearing, teasing and insulting. Teachers 
reprimanded children who used insults, aggravated teasing, swearwords and sexist language among peers, and informed parents about children's use of bad language.

\section{Methodological approach}

A peer language socialization approach - integrating long-term ethnographic studies of children's everyday peer activities combined with approaches for studying talk-ininteraction, i.e. conversation analysis - has influenced the method used here (see Goodwin \& Kyratzis, in press, for an overview). Language practices in multiethnic peer groups were observed and video-recorded over time and across space (on the school yard and in classrooms), thereby enabling the researchers' understanding of linguistic norms and patterns of language use, the participants' shared background knowledge and the interpretative procedures they employ in situated meaning making.

The approach taken provides a way of exploring the constitutive role of talk for local social organization and how issues associated with linguistic ideologies are instantiated and mediated through ethnographically observable peer group practices. A peer language socialization approach offers important insights into how wider societal and educational frameworks of linguistic stratifications are located and mobilized within situated action and talk-in-interaction in children's peer groups (Garrett 2007; Paugh 2005; see also the other contributions in this issue). The concept of heteroglossia focuses further attention on the meanings attributed to linguistic varieties in a larger socio-political field (see Bailey 2007; introduction in this issue).

\section{Subversive exploitation of monolingual norms}

The educational language policies in the school, accentuating the importance of language proficiency in Swedish (phonology, grammar, lexis, pragmatics, literacy skills), were appropriated in multilingual peer groups on a recurrent basis and served multiple social purposes. The children's instantiations of 'correct' Swedish were mobilized through the use of communicative practices such as insulting, ridiculing and aggravated teasing, which in the educational setting were associated with bad language. As will be demonstrated, the ambiguous design of these corrective routines open the door for the children to subversively exploit the monolingual norms-in-being.

\subsection{Positioning through competence claims}

In contrast to teachers' efforts to downplay students' 'limited language proficiency in Swedish', provocations on the schoolyard were usually quite bald: for example “understand Swedish”, “talk Swedish”, “don't you understand Swedish”. Through their collaborative language provocations, the children not only called into question one another's language proficiencies, but also positioned themselves as in the know. The first exchange, which is from the regular class, emerged from a peer group interaction between the three boys Elias, Mario and Jamie, who usually hang around on the schoolyard, playfully commenting on other children's performances and one another's conduct. 
(1) (regular class) ${ }^{1}$

\begin{tabular}{|c|c|}
\hline 1 Elias & han kan inte så himla bra \\
\hline 2 & schvensa (sv. svenska) du \\
\hline 3 & kan ju lära honom de lär \\
\hline 4 & honom svensa så kan du ju \\
\hline 5 & prata med honom \\
\hline 6 Mario & 个SCHVENSA heh heh du kan \\
\hline 7 & inte prata själv \\
\hline 8 Jamie & 个SCHVENSA heheh \\
\hline 9 Elias & $(($ sparkar Jamie $))$ \\
\hline 10 Jamie & $\uparrow d u$ kan inte prata \\
\hline 11 & 个schvensa ((singsong)) \\
\hline 12 & $((\overline{\text { springer iväg }))}$ \\
\hline 13 Elias & men säg till en kusin \\
\hline 14 & som inte kan- \\
\hline 15 Jamie & 个SCHVENSA han kan inte \\
\hline 16 & säga $\uparrow$ svenska \\
\hline 17 Elias & ((rusar efter Jamie \\
\hline 18 & sparkar på honom)) \\
\hline 19 Mario & $(($ skrattar $)) \uparrow \underline{\text { SSHVENSA }}$ \\
\hline 20 Jamie & han kan inte saga \\
\hline 21 & 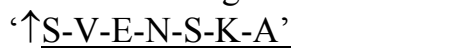 \\
\hline 22 & ((överdrivet uttal) $)$ \\
\hline
\end{tabular}

\author{
he can't speak so good \\ Schwedis (Eng. Swedish), why \\ don't you teach him some \\ Schwedis so you can talk \\ with him \\ $\uparrow S \underline{C H W E D I S}$ heh heh you can \\ not talk yourself \\ $\uparrow$ SCHWEDIS heheh \\ ((kicks Jamie)) \\ 个you can't speak \\ $\uparrow$ Schwedis ((singsong )) \\ ((runs away)) \\ but tell a cousin [who can- \\ $\uparrow$ SCHWEDIS he can't say \\ $\uparrow$ Swedish \\ ((runs after Jamie kicks \\ him, walks back)) \\ ((laughs)) $\uparrow \underline{\text { SSHWEDIS }}$ \\ he can't say \\ ' $\uparrow$ S-W-E-D-I-S-H' \\ ((exaggerated pronunciation))
}

In the example, Elias orients to the category of 'limited language proficiency in Swedish', making claims about proper pronunciation and playfully demanding that Mario teach Jamie how to speak Swedish (lines 1-5). His reference to the epistemic category of 'not knowing' embodies an implicit claim to possessing special knowledge in Swedish. However, the tactic used by Elias is immediately turned against him, as Mario and Jamie start to pick on his pronunciation of the word "svenska" ("Swedish") (lines 6-7). Jamie aligns with Mario by transforming the provocation into a public event of ridiculing marked by singsong intonation and a loud voice (lines 10-11, 15-16, 2021). The recycling combined with the chasing intensifies, sustains and provides the local topic (limited language proficiency) with greater interest. One after the other, the two boys Mario and Jamie recycle their arguments to strengthen alignments, achieve authority and display their linguistic competence in Swedish.

As will be shown in Excerpt 2, mimicking and policing Swedish language use also constitute a special form of norm enforcement in situations of adult supervision in the reception class. In Excerpt 2, the children play the educational game called Memory. The game is organized to elicit the labelling of cards in Swedish and is intended to train

\footnotetext{
${ }^{1}$ The transcription format used is a simplified version of the one used in conversation analysis (CA) (Sacks, Schegloff \& Jefferson 1974). The following transcription conventions apply: . falling intonation; ? rising intonation; , continuing intonation; - abrupt cut-off; o:: prolonging of sound; nine stressed syllable or words, NO high pitch; ${ }^{\circ} \mathrm{no}^{\circ}$ low pitch; hh laughter; [ ] simultaneous or overlapping speech; = contiguous utterances; (.) micro-pause; $\uparrow \downarrow$ rising and falling in intonation; ( ) non-transcribable segment of talk; ((raise their hands)) description of non-speech activity. The English translations in italics are as close as possible to the Swedish verbatim records. All names are fictional.
} 
the children's language knowledge (i.e., personal pronouns "han" (Eng. "he") and "hon" (Eng. "she")). When Abdi picks a card with a picture of a girl, the teacher (who is non-native speaker of Swedish) requests that he label the card (line 1).

\section{(2) (reception class)}

$\begin{array}{lll}\text { 1. TEACHER } & \begin{array}{l}\text { va gör han? ((about a } \\ \text { card)) }\end{array} & \begin{array}{l}\text { what is he doing? ((about } \\ \text { a card)) }\end{array} \\ \text { 2. Abdi: } & \begin{array}{l}\text { HEJ han säger 'vad } \\ \text { gör han' he he }\end{array} & \begin{array}{l}\text { HELLO he says 'what's he } \\ \text { doing?' }\end{array} \\ \text { 3 } & \text { HE HE HE HE } & \text { HE HE HE HE } \\ \text { 4. Fusi: } & \text { >>what is she doing }<< \\ \text { 5. TEACHER } & \text { >>va gör hon<< } \\ \text { 6. Abdi: } & \text { jag kan svenska\# } & \underline{\text { I know Swedish\# }} \\ \text { 7. Fusi: } & \text { he he hon kan soma(h) } & \text { he he she knows } \\ \text { 8. } & \text { liska he he } & \text { Soma(h)li he he } \\ \text { 9. Nok: } & \text { he he he he } & \text { he he he he } \\ \text { 10. Abdi: } & \text { 'borsta tänderna borsta } & \text { borsta tänderna borsta } \\ \text { 11. } & \text { tänderna }{ }^{\circ}((\text { picks cards) }) & \text { tänderna }{ }^{\circ}(\text { picks cards)) }\end{array}$

In the above excerpt, the teacher uses the masculine form of the Swedish pronoun "han" ("he") instead of the feminine form "hon" ("she") (line 1). The language error is immediately commented on by one of the boys, Abdi. Abdi calls the other children's attention to the error, explicitly attributing the use of the pronoun "he" to the teacher: "hej han säger "va gör han"” ("hello he says "what is he doing""), emphatically pronouncing the trouble source "han" ("he") (lines 2-3). One girl in the multilingual peer group, Fusi, immediately aligns with the humorous and critical stance taken by Abdi (line 4). The children's affiliative actions are interpreted as a criticism by the teacher, who quickly corrects his grammatical error (line 5). In response, Abdi claims his expertise in Swedish, "jag kan svenska" ("I know Swedish") (line 6). The use of the epistemic category "kan" ("know") positions Abdi as more knowledgeable than the teacher and upgrades his authority. Ultimately, Fusi reuses the playful framing and elaborates Abdi's argument by ascribing the teacher language competence in a minority language, "Somali" (line 8). In addition, she employs the incorrect feminine form, "hon" ("she"), of the personal pronoun, when she refers to the male teacher, reiterating the teacher's error (lines 7-8). Thereby she foregrounds the teacher's linguistic background as different, which in turn deprives the teacher mastery of Swedish. By limiting the teacher's language competence to knowledge of Somali, the children create an alternative framing of the educational situations in which they, rather than the teacher, hold the position of linguistic and educational authority. In this process, the linguistic resources available are also divided into two separate normatively defined and hierarchically organized codes (e.g., Swedish versus Somali), with 'correct' Swedish as the preferred language.

As shown in Excerpt 1 and 2, the children's picking on one another's as well as teachers' Swedish language errors allows the multilingual peer group to consolidate a collective critical view of not-knowing grammatically and phonologically correct Swedish. The collaborative staging provides a cultural resource for the children to 
enforce monolingual norms and display their understanding of power hierarchies and values associated with particular social languages ('correct' Swedish versus 'immigrant' Swedish). The children's enforcement of 'correct' Swedish highlights that they are not simply victims of an all-powerful linguistic and social order that classifies them as nonproficient language users, but that they creatively appropriate the societal and educational monolingual ideology for their own purposes.

\subsection{Ambiguous recycling of linguistic features of prior talk}

In the following excerpts ( 3 and 4 ), the monolingual norms for language use are indirectly talked into being as the children recycle linguistic features of prior talk to assert a more powerful position in a power struggle. As will be shown, peer accusations are successfully countered and effectively terminated when the linguistic format is made public and picked upon. Such recyclings are ambiguous in that prior talk is not explicitly described as incorrect. Instead, the speaker's deficiency in Swedish is implicated and consolidated through the use of verbatim format, exaggerated prosody, joint laughter and extended repetitions. In Excerpt 3, Jamie's admonishment, "du får inte tjowa" ("you're not allowed to schteal"), indirectly accusing the others of the sanctionable acts of stealing (line 1), is immediately countered and recycled over several turns. Instead of orienting to the propositional content of Jamie's turn, Shafi begins to pick on his Swedish pronunciation of a particular word for stealing "tjowa" (line 2). Jamie has used a vernacular variant "tjuva", pronouncing it in a deviant manner "tjowa" (line 1).

(3) (Regular class)

\begin{tabular}{|c|c|c|}
\hline 1 Jamie & du får inte tjowa & $\begin{array}{l}\text { you are not allowed to } \\
\text { schteal }\end{array}$ \\
\hline 2 Shafi & 个TJOWA $\uparrow$ TJOWA $\uparrow$ TJOWA & ^SCHTEAL \SCHTEAL $\underline{\text { SCHTEAL }}$ \\
\hline & va betyder tjowa & $\overline{\text { what does schteal mean }}$ \\
\hline 4 Elias & va betyder tjowa? & What does schteal mean?, What \\
\hline 5 & va betyder tjowa? & does schteal mean?, What does \\
\hline 6 & va betyder tjowa? & schteal mean?, \\
\hline 7 Shafi & tjowa va betyder de? (.) & Schteal what does it mean? \\
\hline 8 & kanske på ditt språk (.) & (.) maybe in your language \\
\hline 9 & $\mathrm{ja} !$ & (.) yeah! \\
\hline
\end{tabular}

By recycling the phonetic shape of the word "tjowa" eight times, Shafi - supported by Elias - manages to turn Jamie's tactic against him. Thereby the boys strengthen their alignments and construct a local social organization of two-against-one. The two boys' comeback causes Jamie to stop pursuing his accusation. The mispronunciation made available through his talk provides a warrant for changing the topic of 'stealing' into 'limited language proficiency in Swedish'. The boys' repeated recyclings and requests for information about the meaning of the word used by Jamie "vad betyder tjowa" ("what does schteal mean?") in lines 3-7, constitute the word "tjowa" as unintelligible. The topic then glides into a playful but derogatory reference to Jamie's 'linguistic minority background' (line 7). Shafi's use of the possessive pronoun "your language" 
foregrounds Jamie's minority language background as different from those of the other boys. It also disassociates the other boys from the incompetent act of using a minority language among peers (lines 8-9). In this way, Jamie's minority language background is treated as a visible, and non-preferred part of the scene. The boys' pejorative description of Jamie's linguistic background is enabled by a particular local discourse, in which Swedish is defined in terms of its dominant position in relation to minority languages (compare with Ex. 2 lines 7-8).

In next episode, we will demonstrate how three girls playfully exploit a peer's erroneous language performance in a series of evasive recyclings that allow them to successfully refocus the accusation of untoward behaviour.

(4) (reception class)

\begin{tabular}{|c|c|}
\hline 1 Fusi & $\begin{array}{l}\text { HON HA:R (0.5) “Äppelbok" } \\
\text { ((points at Rana)) }\end{array}$ \\
\hline 2 Layla & vem? \\
\hline 3 Fusi & ((points at Rana)) \\
\hline 4 Layla & Rana har inte "Äppelbok" \\
\hline 5 Fusi & $\begin{array}{l}\text { jo ((looks at Layla, } \\
\text { challenging)) }\end{array}$ \\
\hline 6 Layla & ne:ej ((singing) \\
\hline 7 Fusi & jo:o \\
\hline 8 Layla & ((pushes Fusi)) \\
\hline 9 Fusi & INTE SLÅTT mi:g \\
\hline 10 Rana & "inte slå:.tt mi:g" \\
\hline 11 Fusi & $(($ goes away $))$ \\
\hline 12 Layla & $\begin{array}{l}\text { "slå:tt mi:i:g" ((looks } \\
\text { smiling at Rana)) }\end{array}$ \\
\hline 13 Rana & $\begin{array}{l}\text { "stackars Fusi" (("subdued" } \\
\text { voice)) }\end{array}$ \\
\hline
\end{tabular}

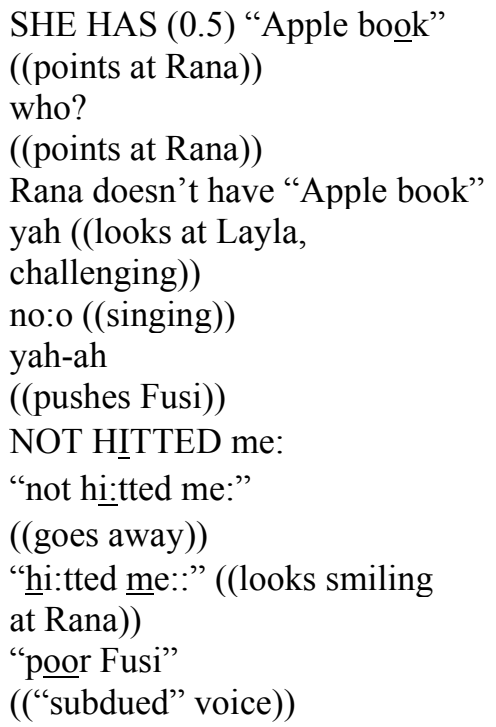

In the above excerpt, the three girls, Rana, Fusi and Layla, are involved in an argumentative sequence, which is escalated and transformed into a corporeal attack as Layla pushes Fusi (line 4-8). In response to that, Fusi screamingly accuses Layla (line 9) of the untoward action of 'hitting'. She, however, uses a wrong verb form "slått", instead of the indefinite form 'slå' ('hit'). It is this Swedish language error that Layla and Rana notice and exploit. The two girls collectively recycle, emphasize and exaggerate the faulty elements in Fusi's turn "slått mig" ("hitted me") (line 10, 12). The careful attention to the faulty grammatical structure of Fusi's turn allows the two girls to display their own specialized knowledge and language competence and to build a powerful alliance against Fusi. The aggravated criticism proves to be a powerful resource in accomplishing a topic shift from 'hitting' to 'limited language proficiency'. The collaborative staging of Fusi's language error provides a warrant for the other girls to successfully counter and terminate the accusation, the effect being that Fusi leaves the scene. In this perspective, it is not surprising to find an explicit mocking consolation of the girl, "stackars Fusi" ("poor Fusi"), who produced the faulty linguistic behaviour being mimicked.

As demonstrated in Excerpt 3 and 4, linguistic norms accentuating phonologically and grammatically correct language use are subversively exploited in children's 
recycling of linguistic features of prior turns to claim authoritative stances, casting other peer group members into more subordinate positions. As shown, the children in the multilingual peer group are at constant risk of being criticized for their insufficient knowledge of Swedish (including pronunciation, verb forms, lexical choice). At the same time, they are provided with similar linguistic resources for retaliating the critique by criticizing others. Each of the linguistic features enumerated above in the children's recyclings are meaningful only in contrast to the monolingual norm at play, accentuating the ideal of native speaker's language competence. A meaningful opposition is (re)produced between linguistic forms associated with a dominant monolingual ideology presently in power and linguistic varieties that index lower positions in social hierarchies (e.g., of the 'non-native' proficiency of bilingual speakers, and minority languages such Kurdish, Romany) (see also Jørgensen 1998). Paradoxically, the monolingual norms are brought into being through extended insulting and teasing, in which the children deliberately break the norms for proper language. The multilayered character of corrective practices serves to attest/displays the children's ambiguous and subversive orientations to educational and linguistic ideologies.

\section{Subverting and exploiting norms regulating 'proper' language use}

Peer interactions in the multilingual peer group also comprised subversion of the educational norms regulating 'proper' Swedish through recurrent use of 'bad' language such as swearing, threats and insults. The following 3 excerpts $(5 \mathrm{a}, \mathrm{b}$ and 6$)$ involve the children's subversive exploitations of the complex array of institutionalized norms regulating language use (i.e., the monolingual norm and the norms for 'proper' language) when using bad language (swearing, insulting, teasing) in code-switching.

\subsection{Code-switching as means of norm-breaking}

Prior to the first excerpt ( 5 a), which takes place in the reception class, one boy (Sawan) in the multilingual peer group had been disciplined by the teacher for swearing at one of the girls (Fusi). In what follows, Fusi, whose ethnic and linguistic background is similar to Sawan's, code-switches into Kurdish and retaliates, telling Sawan "gå khilo", i.e. a childish Kurdish swearword, which literally translates "eat pooh".

(5 a) (reception class).

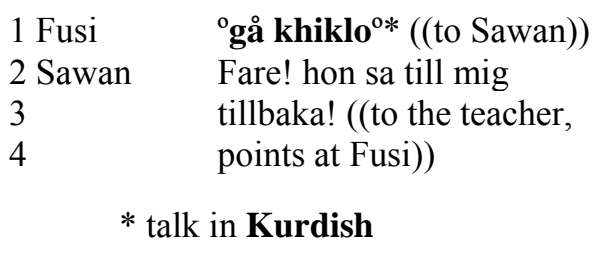

\author{
${ }^{\circ}$ eat pooh $^{\circ}$ ((to Sawan)) \\ Fare! she said the same back \\ to me! ((to the teacher, points at \\ Fusi))
}

Fusi's swearing is well-concealed as it is uttered at a markedly low volume, and in Kurdish, which is Fusi's and Sawan's native language. By code-switching into a minority language the teacher (i.e., Fare) does not know, Fusi collusively exploits the teacher's prohibiting rule for use of bad language and redefines it in a bilingual context. 
This in turn allows her to effectively strike back and discredit the child who performed the untoward action. Usually, swearing, if overheard by or reported to the teacher, has significant consequences for the children. Fusi's off-floor swearing in Kurdish however, warrants Sawan to code-switch into Swedish and call the teacher's attention to the fact that Fusi is culpable of a similar untoward action (i.e., swearing back) ("she said the same back to me", lines 2-4). Sawan's telling on Fusi transforms the concealed collusive code-switched act of swearing into a public event. By code-switching into Swedish and calling on the teacher, Sawan not only manages to shame Fusi for her linguistic misbehaviour but also to mitigate his own abusive act of swearing, thereby asserting his own social position as a "good monolingual student" (Cekaite \& Evaldsson 2008).

However, Sawan does not succeed in his attempt to gain the teacher's attention. Soon after, he instead code-switches into Kurdish and initiates a subversive insult sequence in return. This time, one more child, Hiwa, whose native language is also Kurdish, takes part in the collusive acts.

(5b) (reception class).

Part 2.

1 Sawan

2

3

4

5 Hiwa

6

7

8 Fusi

9 Sawan

10

11

12 Fusi

13 Sawan

14

15

16 Hiwa

17

18 Sawan

19 Fusi

20 Sawan

21

22 Fusi

30 Sawan

31

32 Fusi

33 Sawan

34 Hiwa he he he ((kicks Fusi's

chair)) Fusi! (.) atu $\mathbf{j}$

wani?* ((smiling,

pretend kind voice))

((smiles at Sawan,

then looks at Fusi))

basha he he

((looks at her book))

atu je wani, Fusi?

((smiling, pretend kind

voice))

(2) ((looks at her book)

atu atu $\mathbf{j}$ wani? ((looks

at Fusi, then turns to

Hiwa))

((smiling looks at Fusi

and Sawan))

atu je wani?

JAG KAN SKRIV

MATTEBOKEN

atu je wani? (malicious

voice))

skriv matteboken Fare!

((teacher instructs Fusi))

((when teacher leaves,

Sawan addresses Fusi again))

atu atu $\mathbf{j}$ wani?

(('naïve' voice))

((looks at her book))

atu nie $\mathbf{j}$ wani! he he

((looks 'surprised', turns to the teacher)) he he he ((kicks Fusi's

chair)) Fusi! (.) are you

pretty? ((smiling,

pretend kind voice))

((smiles at Sawan,

then looks at Fusi))

okay he he

((looks at her book)

are you you pretty, Fusi?

((smiling, pretend kind

voice))

(2) ((looks at her book))

are you you pretty? (looks

at Fusi, then turns

to Hiwa))

((smiling looks at Fusi

and Sawan))

are you pretty?

I CAN WRITE MATH BOOK

are you pretty? ((malicous

voice))

Write math book Fare!

are you pretty?

(('naïve' voice))

((looks at her book))

you are not pretty! he he

((looks 'surprised', turns

to the teacher) 


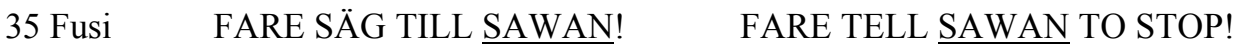

* talk in Kurdish

Sawan launches his attack on Fusi by code-switching into Kurdish (Fusi's, Sawan's and Hiwa's native language) and asking Fusi "atu j wani", which literally translates as the question "are you pretty?". The switch into Kurdish also functions to hide the meaning of the talk from the non-Kurdish-speaking teacher standing nearby. The design of the talk (pretend kind voice and smiling, code-switching, recycling) strongly indicates the subversive pejorative character, implicitly invoking a negative person description (implying that the recipient is not pretty). In what follows, Sawan recycles his codeswitched question six times (lines 2-3, 8, 13, 18, 20). (Only in case if numbers starting from line 6 are revised in the Ex. 5b). Sawan's recycled question initiates a "character contest" (Goffman 1967), given that a response easily can be interpreted as a selfincriminating move and might be turned against the speaker. As Goffman notes, the character contest is "a special kind of moral game" (ibid. p. 240) that is concerned with discrediting the adversary while at the same time gathering evidence in support of one's own strength. The subversive insult format is inference rich: it is also used to shame the recipient for her misbehaviour: using bad language. The recycling intensifies, is sustained and provides the local topic (using bad language) with greater interest (Goodwin 1990; Evaldsson 2005). It also integrates some risky elements, if overheard by or reported to the teacher. The language alternation to Kurdish, Hiwa's laughing evaluation "basha he he" (Eng. "Okay he he") in lines 6-8 and the two boys' mutual gazes and smiling (lines, 10-11-12, 14-15, 16-17) (Only in case if the number starting from line 6 are revised in the Ex. 5b). accentuate the collusiveness of the acts. Simultaneously, these behaviours ratify and strengthen the boys' alignment against Fusi.

Despite the numerous provocations, Fusi avoids answering the persistent attempts made by Sawan, which in turn leads to an escalation of the conflict when Sawan delivers the answer himself, "you are not pretty" (line 33), emphasizing the pejorative description of Fusi. In response, Fusi immediately shifts in footing and takes the opportunity to retaliate, loudly demanding in Swedish that the teacher scold Sawan (line 35). Fusi's call for the teacher to intervene carries a sense of a serious disciplining action, which indexes her own creative appropriation and exploitation of the norms for 'proper' language use at work in school. The ambiguity in the indexical meaning of insulting, teasing and swearing is maintained and expanded through the use of minority languages in heteroglossic peer play, partly against the wishes of adults (cf. Garrett 2007; Paugh 2005).

\subsection{Ritual and personal insults as sanctionable actions}

The combined use of code-switching to a minority language and insulting involves mobilizing multiple linguistic norms and juxtaposing them against each other when handling power dynamics in the peer group along with the language policy at school. As will be illustrated in the last excerpt from the schoolyard, four children, two boys, Elias and Jamie with different ethnic and linguistic backgrounds (Syrian versus Romany) and two girls, Tatja (Romany) and Lisa (Syrian), engage in heteroglossic peer play, using a 
subversive form of ritualized insult format, which ordinarily attributes a pejorative (sexual) value to the mother or the father of the target (Labov 1972: 322). In what follows Jamie combines the subversive insult format with a pejorative Romany name, "Jomai", to playfully humiliate Elias and say something derogatory about his mother and father (lines 1-3). Such deliberate norm-breaking of proper language use is not only seen as funny, exciting, and powerful, but also as a potentially sanctionable event.

(6) (regular class)

\begin{tabular}{|c|c|c|}
\hline 1 Jamie & HONOMS PAPPA HETER & HIMS FATHER'S NAME IS \\
\hline & 个JOMAI HONOM MAMMA HETER & R个JOMAI HIMS MOTHER'S NAME IS \\
\hline 3 & 个JOMAI* ((singsong)) & 个JOMAI ((singsong)) \\
\hline 4 Elias & ni två e kusiner ((till & you two are cousins ((to Tatja \\
\hline 5 & Tatja och Jamie)) & and Jamie)) \\
\hline 6 Tatja & $\mathrm{SÄG}$ åt honom! ((till & TELL him to stop ((to the \\
\hline 7 g Jamie & de andra)) & others)) \\
\hline 8 Jamie & honoms mamma heter också & hims mother's name is also \\
\hline 9 & 个Jomai Jomai Jomai & 个Jomai Jomai Jomai \\
\hline 10 & ((skrattar)) & ((laughs)) \\
\hline 11 Tatja & 个TIIG DIN DJ्̈̈VLA BÖG! & 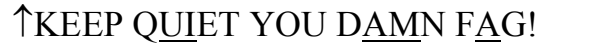 \\
\hline 12 Lisa & ((tittar omkring lägger & ((looking around and puts her \\
\hline 13 & handen över Tatja's mun)) & hand over Tatja's mouth)) \\
\hline 14 Jamie & 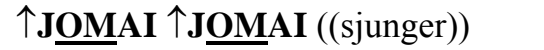 & 个JOMAI $\uparrow \mathbf{J O M A I}(($ singing $))$ \\
\hline 15 Lisa & ((lägger handen över sin & ((puts her hand over her own \\
\hline 16 & mun)) ingen säger till & mouth)) nobody tell the \\
\hline 17 & fröken, säg inte till & teacher, don't tell the \\
\hline 18 & fröken! ((tittar in i & teacher! ((looks in the \\
\hline 19 & kameran)) & camera)) \\
\hline
\end{tabular}

The code switching into a nonsensical Romany name is multifunctional and connected to different forms of norm transgressions. The use of Romany, an out-group language, not understood by the recipient (Elias), mitigates the risks and dangers associated with the use of sexist language among peers. Deployment of the pronoun "his" (expressed with a faulty element as "hims") instead of "yours" transforms the abusive sexual language into a public event, which makes it more difficult to strike back (lines 1-3). Furthermore, the ritualized insult format, together with playful voices, laughter and the code-switch, indicates that Jamie uses an abusive sexual language that transgresses the language policy in school. As Sacks (1992) suggests in his discussion of a dirty joke, the fun of such activity is not the sexual content, but the fact that the children appropriate and exploit an adult rule about a prohibited linguistic behaviour.

Although the sexual abuse is not addressed to Tatja, the Romany girl, she reacts to the insulting with emotional strength and a negative response "tell him to stop" (line 6). Her call for help indexes sexual language as bad language and a potentially sanctionable event in relation to the norms-in-being for proper language use in school. As shown, Tatja's negative response does not stop Jamie from pursuing his actions, but instead renders the use of bad language more vivid and captivating (line 8-10). Finally, Tatja 
produces an aggravated imperative ("keep quiet!") and a sexual insult ("you damn fag!") in Swedish to stop Jamie from pursuing his insulting (line 11). The immediate response from the other girl Lisa, such as when she puts her hand over her own mouth to ensure that nobody tells the teacher (lines 12-13), demonstrates that the use of swearing and sexist language in Swedish is a sanctionable event in school.

Lisa's efforts to silence Tatja demonstrate not only the abrupt shift in footing from a playful display in the multilingual peer group to the world of teacher-ruled linguistic ideologies, but that the children exploit the institutionalized norms for proper Swedish to reconstitute the power dynamics in the peer group (see also Excerpt 5a lines 2-4 and $5 \mathrm{~b}$ line 35). Simultaneously the children's appropriation of the language policy of school is used to collusively exploit and "counterpose a proposed violation" (Sacks 1992, vol. 2, p. 492). The ambiguity towards the linguistic norms at play, regulating the children's use of Swedish and bad language, provides for and expands the dynamic and entertaining potentials of heteroglossic peer play.

\section{Concluding discussion}

In Bakhtin's (1986: 270) view, linguistic norms regulating the use of unitary language "do not constitute an abstract imperative; they are rather the generative forces of linguistic life, forces that struggle to overcome the heteroglossia of language". As we have shown, monolingual educational language ideologies comprising the use of correct and proper language are actively exploited, enforced and even resisted by children and constitute an integral part of their heteroglossic peer play. In an educational setting where mastery of the majority language (i.e., Swedish) is presented as central in the curriculum and has a crucial role in educational practice, minority schoolchildren's use of social languages and different codes is ideologically charged, and not a value-neutral activity (cf. Schieffelin, Woolard \& Kroskrity 1998; see also Kyratzis, this volume). As shown, the children display their ideological orientation towards the majority language through mimicking, teasing and criticizing one another's language use, even when not under adult supervision. In their displays of linguistic expertise and enforcement of linguistic norms, the children reproduce the hierarchical relationship between proper/correct Swedish and other linguistic varieties and forms. Within these heteroglossic practices, the children display their sensitivity to and create associations between proper language and school authorities, status and power. Such hybrid practices are fed by incongruent cultural values that render their social meaning ambiguous. Moreover, by mainly locating minority languages within the domain of bad language (swearwords, sexist language, insults), the children establish linkages between bilingualism and bad language, autonomy and resistance to the monolingual ideology.

The heteroglossic peer play practices are instantiated through seemingly trivial corrective routines that involve the use of a combination of different forms of linguistic, communicative and social resources. By commenting on, mimicking and teasing one another for deficient/improper use of the majority language (i.e., Swedish), the children establish who is in-the-know and cast the others into more subordinate positions, claim their proficiency in the majority language and enforce monolingual norms for language use. At the same time, the collusive use of bad language (swearwords, sexist language, insults) and code-switching provides the children with efficient resources in peer power 
struggles, forming part of the creative interpretative processes in heteroglossic peer play.

The detailed analysis also demonstrates the linguistic competences used, such as children's careful attention to linguistic aspects of prior turns (including pronunciation, prosody, verb forms, lexical choices, syntactic shape, turn-structure, etc.). The children deploy multiple resources provided by the talk of the prior speaker and the turn structure of different activities (conflicts, accusations, insults, games, classroom discourse). They transform this talk by repeating structural elements, recycling arguments, shifting emphasis and using format tying, parodic imitations, and joint laughter to collaboratively stage counter-moves, render joint commentary and refocus accusations of untoward behaviours. Repetition and recycling involve intricate language skills and abilities to analyse the format (phonetic, lexical choice, syntactic) of prior turns (Cekaite \& Aronsson 2004; Goodwin 1990; Evaldsson 2005; Reynolds 2007), which also increase the excitement and intensify the event, rendering it public, more vivid and captivating, providing communicative resources to reorganize the peer group and negotiate linguistic norms.

Overall, our study demonstrates that children's exploitation and reproduction of the linguistic norms-in-being is not simply the result of teacher interventions or part of an alien adult practice that is passively internalized or simply resisted. Interestingly, minority school children's everyday heteroglossic practices in multilingual peer groups constitute a critical site for active reproduction of the monolingual norms-in-being, which in turn differs from what is found among adolescents (Jørgensen 2005; Rampton 1995). ${ }^{2}$ Paradoxically, such forms of playful heteroglossic peer group practices tend to enforce power hierarchies in which the language varieties associated with minority children become subordinated, marginalized, and seen as diverging from the ideal (and national) standard (cf. Bailey, 2007). However, the highly ambiguous and hybrid forms of linguistic resources, manifested in the minority school children's creative appropriation of hegemonic values regarding language, might change the norms for how (national) language ought to work.

\section{Acknowledgements}

We would like to acknowledge the support and input of Amy Kyratzis, Jennifer Reynolds, Susan Ervin-Tripp and three anonymous reviewers. The research reported here was supported by grants from Knut and Alice Wallenberg Foundation, Riksbankens Jubileumsfond and the Swedish Research Council.

\section{References}

Bailey, Benjamin (2007) Heteroglossia and boundaries. In Monica Heller (ed.), Bilingualism: A Social Approach. New York: Palgrave Macmillan, pp. 257-74.

${ }^{2}$ As demonstrated in research among adolescents in multiethnic educational settings, switches between multiple languages provide a resource that is widely used as a means for resisting a monolingual educational order and adult norms for language use (see Jørgensen 2005; Rampton 1995). 
Bakhtin, Michail (1986) Speech genres and other late essays. Austin: University of Texas Press.

Cameron, Deborah (1995) Verbal hygiene. London: Routledge.

Cekaite, Asta (2007) A child's development of interactional competence in a Swedish L2 classroom. The Modern Language Journal 91: 45-62.

Cekaite, Asta, and Karin Aronsson (2004) Repetition and joking in children's second language conversations: Playful recyclings in an immersion classroom. Discourse Studies 6.3: 373-392.

Cekaite, Asta, and Ann-Carita Evaldsson (2008) Staging linguistic identities and negotiating monolingual norms in multiethnic school settings. Journal of Multilingualism 5.3: 177-196.

Evaldsson, Ann-Carita (2004) Shifting moral stances: Morality and gender in same-sex and cross-sex game interaction. Research on Language and Social Interaction 37: 331-363.

Evaldsson, Ann-Carita (2005) Staging insults and mobilizing categorizations in a multiethnic peer group. Discourse in Society 16: 763-786.

Garrett, Paul (2000) 'High Kweyol': The emergence of a formal creole register in St. Lucia. In J. McWorther (ed.), Language change and language contact in Pidgeons and Creoles. Amsterdam: John Benjamins Publishing Company, pp. 155-210.

Garrett, Paul (2007) Language socialization and the (re)production of bilingual subjectivities. In Monica Heller (ed.), Bilingualism: A social approach. Hampshire: Palgrave Macmillian, pp. 233-255.

Goffman, Erving (1967) Interaction Ritual: Essays in Face to Face Behavior. Garden City, NY: Doubleday.

Goodwin, Marjorie Harness (1990) He-said-she-said: Talk as social organization among black children. Bloomington and Indianapolis: Indiana University Press.

Goodwin, Marjorie Harness, and Amy Kyratzis (in press) Peer Socialization. In Alessandro Duranti, Elinor Ochs, \& Bambi Schieffelin (eds.), The Handbook of Language Socialization. Oxford, U.K.: Blackwell.

Hinnenkamp, V. (2003) Mixed language varieties of migrant adolescents and the discourse of hybridity. Journal of Multicultural and Multilingual Development 24.1\&2: 12-41.

Jørgensen, Normann Jens (1998) Children's acquisition of code-switching for power-wielding. In P. Auer (ed.), Code-switching in Conversation: Language, Interaction and Identity . London: Routledge, pp. 237258.

Jørgensen, Norrmann Jens (2005) Plurilingual conversations among bilingual adolescents. Journal of Pragmatics 37: 391-402.

Kulick, Don (1992) Language shift and cultural reproduction. Cambridge: Cambridge University Press.

Kyratzis, Amy (this volume) Latina girls' peer play interactions in a bilingual Spanish-English US preschool: Heteroglossia, frame-shifting, and language ideology. Pragmatics 20.4.

Labov, William (1972) Language in the Inner City: Studies in the Black English Vernacular Studies. Philadelphia, PA: University of Pennsylvania.

Lytra, Vally (2007) Play Frame and Social Identities: Contact Encounters in a Greek Primary School. Amsterdam: John Benjamins Publishing Company. 
Madsen, L.M. (2008) Un Deux Trois - Speak English! Young taekwondo-fighters' identity construction through linguistic competition. International Journal of Multilingualism 5: 197- 217.

Minks, Amanda (this volume) Socializing heteroglossia among Miskitu children on the Caribbean Coast of Nicaragua. Pragmatics 20.4

Paugh, Amy (2005) Multilingual play: Children's code-switching, role-play, and agency in Dominica, West Indies. Language in Society 34: 63-86.

Rampton, Ben (1995) Crossing: Language and Ethnicity among Adolescents. London. Longham.

Rampton, Ben (2006) Language in Late Modernity. Interaction in an Urban School. Cambridge: Cambridge University Press.

Reynolds, Jennifer (2007) Buenos Dias/ (Military Salute): The natural history of a coined insult. Research on Language and Social Interaction 40: 437-466.

Rindstedt, Camilla, and Karin Aronsson (2002) Growing up monolingual in a bilingual community. Language in Society 31: 721-42.

Sacks, Harvey (1992) Lectures on Conversation. Volume 2. Oxford MA: Blackwell.

Sacks, Harvey, Emanuel Schegloff, and Gail Jefferson (1974) A simplest systematics for the organization of turn-taking for conversation. Language 50: 696-735.

Schieffelin, Bambi, Kathryn Woolard, and Paul Kroskrity (eds.) (1998) Language ideologies: Practice and theory. Oxford: Oxford University Press.

Woolard, Kathryn (1997) "Between friends: Gender, peer group structure and bilingualism in urban Catalonia.” Language in Society 26.4: 533-560.

ANN-CARITA EVALDSSON is a professor at the Department of Education, Uppsala University. Her main area of interest is children's peer language socialization in educational settings, focusing on children's everyday language practices (gossip, disputes, insults), play and games as situated activities, morality in interaction and identity work (gender, class and ethnicity).

Address: Department of Education, Uppsala University, Box 2136, 75002 Uppsala, Sweden. E-mail: ann-carita.evaldsson@ped.uu.se

ASTA CEKAITE is an associate professor at the Department of Child studies, Linköping University, Sweden. From a language socialization perspective, she focuses on first and second language socialization and learning, embodied and affective features of social interaction, children's language play and discourse in formal and informal (family and peer group) settings.

Address: Department of Child Studies, Linköping University, SE-581 83 Linköping, Sweden. E-mail: asta.cekaite@liu.se 